\title{
(4t) \\ Manipulating Water in High-Performance Hydroxide Exchange Membrane Fuel Cells through Asymmetric Humidification and Wetproofing
}

\author{
Robert B. Kaspar, Michael P. Letterio, Jarrid A. Wittkopf, Ke Gong, Shuang Gu, \\ and Yushan Yan*,z \\ Department of Chemical and Biomolecular Engineering, University of Delaware, Newark, Delaware 19716, USA
}

\begin{abstract}
Hydroxide exchange membrane fuel cells (HEMFCs) are an emerging low-cost alternative to conventional proton exchange membrane fuel cells. In addition to producing water at the anode, HEMFCs consume water at the cathode, leading to distinctive water transport behavior. We report that gas diffusion layer (GDL) wetproofing strictly lowers cell performance, but that the penalty is much higher when the anode side is wetproofed compared to the cathode side. We attribute this penalty primarily to mass transport losses from anode flooding, suggesting that cathode humidification may be more beneficial than anode humidification for this device. GDLs with little or no wetproofing perform best, yielding a competitive peak power density of $737 \mathrm{~mW} \mathrm{~cm}^{-2}$.

(C) The Author(s) 2015. Published by ECS. This is an open access article distributed under the terms of the Creative Commons Attribution 4.0 License (CC BY, http://creativecommons.org/licenses/by/4.0/), which permits unrestricted reuse of the work in any medium, provided the original work is properly cited. [DOI: 10.1149/2.0131506jes] All rights reserved.
\end{abstract}

Manuscript submitted December 23, 2014; revised manuscript received February 11, 2015. Published February $20,2015$.

Proton exchange membrane fuel cells (PEMFCs) have shown high performance but may prove unsustainable in mass production due to their dependence on scarce catalysts like Pt. An emerging alternative technology, the hydroxide exchange membrane fuel cell (HEMFC), ${ }^{1}$ is increasingly competitive with PEMFCs ${ }^{2-5}$ and supports earth-abundant catalysts like Ni and Ag. ${ }^{6,7}$

Whereas PEMFCs have been modeled and optimized meticulously, ${ }^{8-11}$ HEMFC materials and operating conditions are still under active investigation. Because the two systems seem to differ only in minor ways, it is natural to apply general findings from the more mature PEMFC to HEMFC development. For example, in PEMFCs hydrophobized gas diffusion layers (GDLs) with microporous layers (MPLs) were introduced in part to mitigate cathode flooding at high current. ${ }^{12}$ In HEMFCs the hydrogen oxidation reaction (HOR) produces water so in principle the anode is analogously susceptible to flooding; yet, while GDL thickness has been studied in the HEMFC literature, ${ }^{4}$ there is little discussion of hydrophobic treatment or MPLs., ${ }^{3,13-15}$ Cathode drying is also a potential concern for HEMFCs because the oxygen reduction reaction (ORR) consumes water (Scheme 1). ${ }^{14}$

Surprisingly, water management strategies have been adopted in which cathode humidification is eliminated ${ }^{16}$ or greatly reduced ${ }^{14}$ (despite potential cathode drying) and instead only the anode is fully humidified (despite potential anode flooding). It has been shown that the resultant concentration gradient increases water flux through the cathode, ${ }^{16}$ but an explanation has yet to be published for why these indirect approaches should be more effective than humidifying the drying-prone cathode directly.

Here we present a high-performance HEMFC made from commercially available materials. We demonstrate flooding and drying by manipulating humidification and GDL wetproofing. We show that wetproofing is detrimental because it floods the anode, and that dryanode operation leads to higher performance than dry-cathode operation. We describe flooding and drying behavior semi-quantitatively through a simplistic water diffusion model.

\section{Experimental}

Membrane-electrode assemblies (MEAs) were fabricated by depositing $5 \mathrm{~cm}^{2}$ electrodes onto both sides of a membrane (Tokuyama Corp. A201 or A901) with a robotic sprayer (Sono-Tek ExactaCoat). The electrode ink was prepared by adding $250 \mathrm{mg}$ of catalyst (Tanaka Kikinzoku Kogyo, or TKK, 50\% Pt on high-surface-area C) and the desired amount of ionomer (Tokuyama Corp. AS-4) to $10 \mathrm{~g}$ of water and $10 \mathrm{~g}$ of isopropanol, followed by sonicating for 1 hour. The catalyst loading was $0.4 \mathrm{mg}_{\mathrm{Pt}} \mathrm{cm}^{-2}$.

The sandwich was completed by adding a PTFE-coated fiberglass gasket, a GDL (Toray TGP-H-060, SGL 25 BA, or SGL 25 BC), and a graphite flow field (ElectroChem) to each side of the MEA. The GDLs were used as received: either unwetproofed, or wetproofed with 5, 10, 20 , or $50 \mathrm{wt} \%$ PTFE. The manufacturer wetproofed the Toray paper by dipping into a PTFE suspension followed by high-temperature drying.

Performance was characterized with a fuel cell test system equipped with a back pressure module (Scribner 850e). Normally, the cell was activated by scanning current, beginning at zero and ending when the voltage dropped below $150 \mathrm{mV}$. For experiments in which one or both sides of the cell were completely unhumidified, a high-current activation was used instead to generate more water: the cell voltage was fixed at $50 \mathrm{mV}$ for 20 minutes. After activation, performance was recorded by scanning current in the same manner as normal activation. Internal resistance (IR) was monitored continuously by a current interrupt method built into the fuel cell test system. Because we observed a decrease in IR with current, all point values were measured at $500 \mathrm{~mA} \mathrm{~cm}^{-2}$.

\section{Theoretical}

To model the water distribution within the cell, Fick's laws of diffusion were applied piecewise on the membrane, GDLs, and

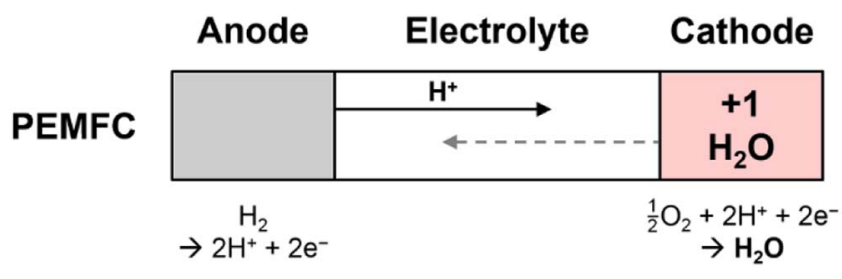

HEMFC

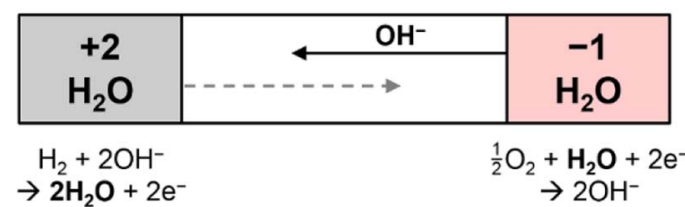

Scheme 1. Water generation, consumption, and movement in proton and hydroxide exchange membrane fuel cells. Arrows indicate direction of water transport through electro-osmotic drag (solid lines) and diffusion (dashed lines). 
Table I. Model parameters.

Parameter

Effective diffusion coefficient of water in membrane

Effective diffusion coefficient of water in unwetproofed GDL

Effective diffusion coefficient of water in $50 \%$ wetproofed GDL

Effective diffusion coefficient of water in CL

Source term in anode CL

Source term in cathode CL

Number of water molecules each hydroxide ion carries

Thickness of membrane

Thickness of CL

Thickness of GDL

Water concentration in humidified feed

Water concentration in unhumidified feed

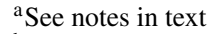

${ }^{\mathrm{b}}$ Wetproofing is assumed to lower porosity as described in the discussion

${ }^{\mathrm{c}}$ Assumed to be similar to the wetproofed GDL

${ }^{\mathrm{d}}$ Calculated based on a current density of $500 \mathrm{~mA} \mathrm{~cm}^{-2}$

${ }^{\mathrm{e}}$ Typical value; see for example Gasteiger et al. $(2005)^{11}$

${ }^{\mathrm{f}}$ Calculated assuming passing through a $70^{\circ} \mathrm{C}$ humidifier saturates the feed

catalyst layers (CLs), with source and sink terms in the CLs and an electro-osmotic drag term in the membrane and CLs, as follows:

$$
\frac{\mathrm{d} c}{\mathrm{~d} t}=s-\frac{\mathrm{d}}{\mathrm{d} x}\left(J_{\text {diffusion }}+J_{\text {electro-osmosis }}\right)
$$

where the flux terms are

$$
\begin{gathered}
J_{\text {diffusion }}=-D \frac{\mathrm{d} c}{\mathrm{~d} x} \\
J_{\text {electro-osmosis }}=n \Phi(x),
\end{gathered}
$$

$c$ is water concentration, $t$ is time, $s$ is a source for HOR or sink for ORR, $D$ is the effective diffusion coefficient, $x$ is position (increasing from anode to cathode), and $n$ is the number of water molecules each hydroxide ion carries. $\Phi$ is the flux of hydroxide ions: zero in the GDLs, constant in the membrane, and a linear ramp function in the CLs (see assumptions below). The external boundary conditions are fixed concentration at the flow channels depending on humidification, and the interfacial boundary conditions are continuity of concentration and flux. At steady state integrating twice yields

$$
c=\frac{1}{D}\left[n \int \Phi(x) \mathrm{d} x-\frac{s}{2} x^{2}+\alpha x+\beta\right]
$$

for each region. The integration constants $\alpha$ and $\beta$ were found by solving the model equations and boundary conditions together as a linear system.

Table I shows the values of the model parameters. ${ }^{17-22}$ A high value was chosen for the effective diffusion coefficient in the membrane $\left(5 * 10^{-7} \mathrm{~m}^{2} \mathrm{~s}^{-1}\right.$ vs. $10^{-10}$ to $\left.10^{-9} \mathrm{~m}^{2} \mathrm{~s}^{-1}\right)$. With lower values, a large concentration drop is predicted and the cathode concentration falls below the boundary humidification level, which would contradict the observation of Zhang et al. that both outlets contain liquid water regardless of current density. ${ }^{22}$

The most important limitation of the model is that all water is assumed to exist in the gas phase. Equilibrium with a liquid phase was ignored for simplicity. Additionally, electro-osmotic drag was summarized in a single constant parameter despite known dependence on hydraulic pressure and back-diffusion rate. ${ }^{9}$ Other assumptions include: that current is generated evenly in the CLs, that diffusion coefficient is not a function of position within each region, and that the cell is isothermal.

In light of these limitations, the model should be treated only as semi-quantitative. It is too simplistic to apply predictively without validation. Here, we use it only to illustrate and support arguments that are based primarily on experimental evidence.

\section{Results and Discussion}

Choosing an appropriate ionomer loading in the catalyst layer is critical to HEMFC performance. We prepared MEAs by the catalystcoated membrane method, with ionomer loadings from 10 to $30 \mathrm{wt} \%$, and found a clear optimum near 20\% (Fig. 1) in agreement with Yang et al. ${ }^{23}$ This optimum loading results from a tradeoff: too little ionomer lowers catalyst utilization due to insufficient ion-conducting channels, while too much reduces both mass transport due to pore clogging and electrical conductivity due to separation of catalyst particles. Additionally, the hydrophilic ion-conducting groups may affect the water distribution in the cell, but we fixed the ionomer loading at $20 \%$ to study other factors that control water transport: GDL wetproofing and humidification.

Identical MEAs were fabricated with an automated sprayer, assembled with macroporous-only Toray GDLs of various wetproofing levels $(0,5,10,20$, or $50 \mathrm{wt} \%$ PTFE), and tested. High PTFE levels drastically reduced performance, in particular when applied on the anode side, and even low levels had a noticeable negative effect (Fig. 2). In PEMFCs, surface hydrophobization of GDL pores normally prevents water from accumulating at the electrodes, ${ }^{12,24}$ so the obvious interpretation of Fig. 2 is that wetproofing dries out the cell, resulting in ohmic losses from low electrolyte hydration and potentially cathode mass transport losses from insufficient water availability for ORR.
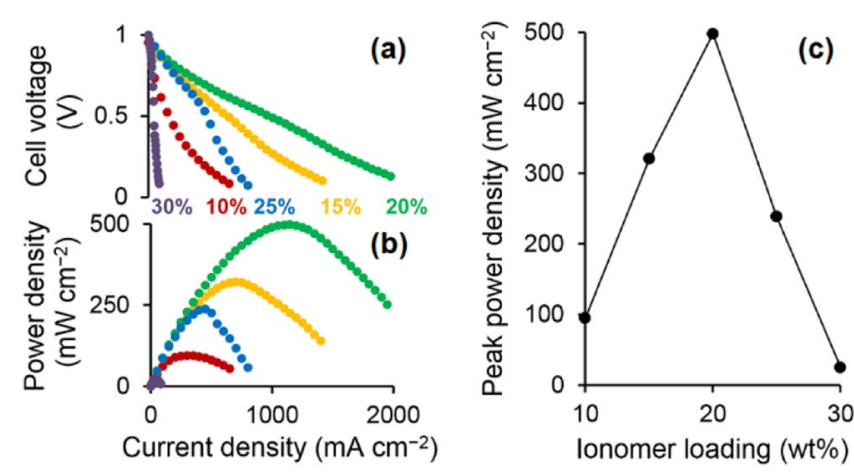

Figure 1. (a) Polarization curves, (b) power density curves, and (c) peak power densities of MEAs prepared with ionomer loadings from 10-30 wt $\%$. Materials: Tokuyama A901 membrane, Tokuyama AS-4 ionomer, catalyst loading of $0.4 \mathrm{mg}_{\mathrm{Pt}} \mathrm{cm}^{-2}$ TKK $50 \% \mathrm{Pt} / \mathrm{C}, 10 \%$ PTFE in Toray GDLs. Test conditions: cell at $60^{\circ} \mathrm{C}$, anode and cathode humidifiers at $70^{\circ} \mathrm{C}, \mathrm{H}_{2}$ and $\mathrm{O}_{2}$ flow rates of $0.2 \mathrm{~L} / \mathrm{min}$ and back pressures of $250 \mathrm{kPag}$. 

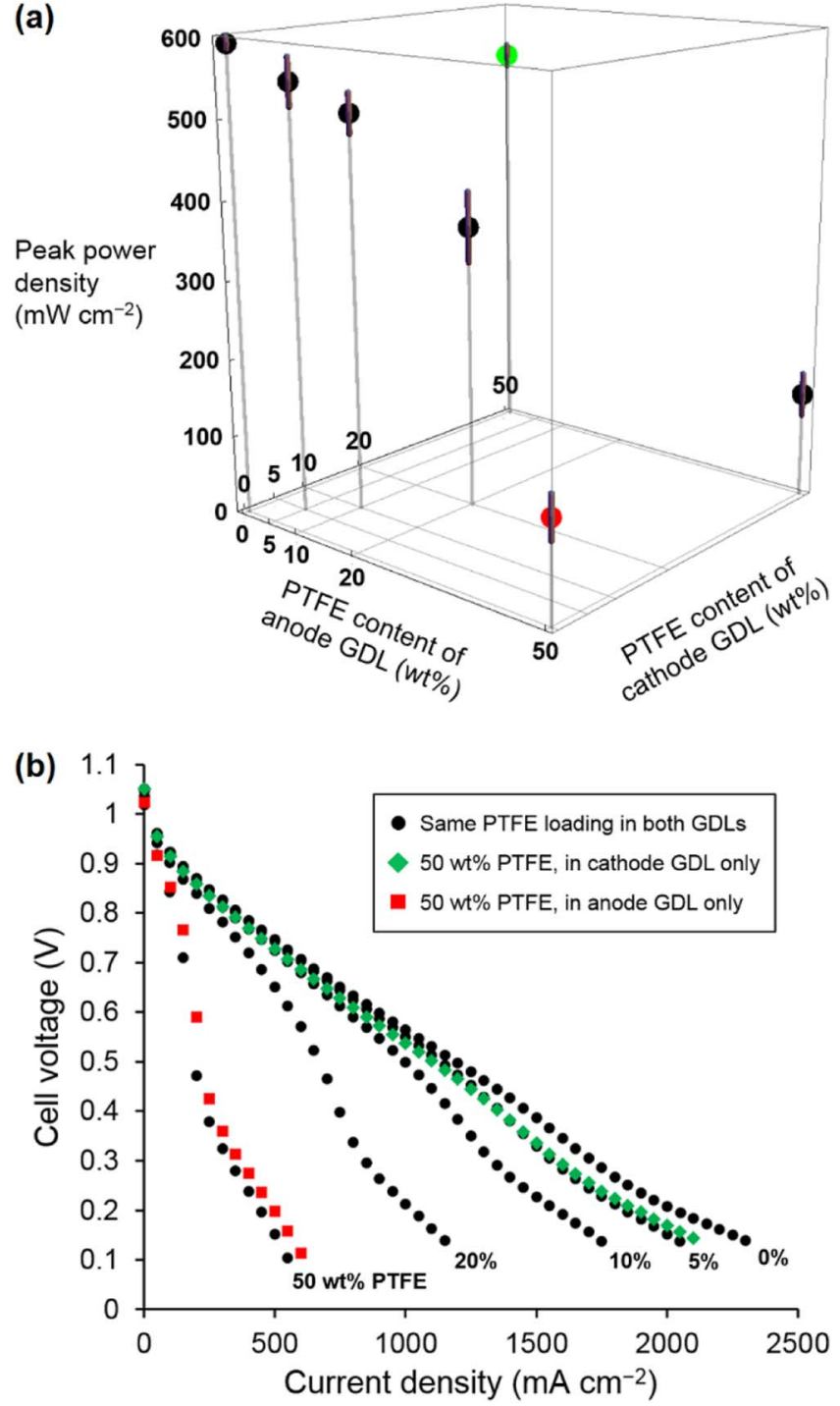

Figure 2. Impact of GDL wetproofing on cell performance. (a) Each dot represents the average peak power density of MEAs tested with equal wetproofing on both GDLs (black), wetproofing only on the anode GDL (red), or wetproofing only on the cathode GDL (green). Error bars indicate \pm 1 standard error $(\mathrm{n}=3)$. (b) Representative polarization curves. Materials: Tokuyama A901 membrane, ionomer loading of $20 \%$ Tokuyama AS-4, catalyst loading of $0.4 \mathrm{mg}_{\mathrm{Pt}} \mathrm{cm}^{-2}$ TKK 50\% Pt/C. Test conditions: cell at $60^{\circ} \mathrm{C}$, anode and cathode humidifiers at $70^{\circ} \mathrm{C}, \mathrm{H}_{2}$ and $\mathrm{O}_{2}$ flow rates of $0.2 \mathrm{~L} / \mathrm{min}$ and back pressures of $250 \mathrm{kPag}$.

To test this interpretation, we measured the cell internal resistance (IR). IR is sensitive to flooding and drying because the electrolyte only conducts well in the presence of water, whose solvating effect frees the hydroxide ions to migrate through the cell. Surprisingly, for the 21 MEAs tested in Fig. 2 the IR did not vary substantially (84-108 $\left.\mathrm{m} \Omega \mathrm{cm}^{2}\right)$. The corresponding variation in ohmic losses (42$54 \mathrm{mV}$ ) accounts for only $2 \%$ of the observed variation in performance $(114-746 \mathrm{mV})$ at a current density of $500 \mathrm{~mA} \mathrm{~cm}{ }^{-2}$. This IR uniformity indicates that the electrolyte was adequately hydrated in all cases, likely due to the high level of humidification $\left(\mathrm{T}_{\text {hum }}=\mathrm{T}_{\text {cell }}+10^{\circ} \mathrm{C}\right)$, and rules out the possibility that wetproofing significantly dries out the electrolyte.

To investigate further, we performed controlled-current tests with relatively low humidification $\left(\mathrm{T}_{\text {hum }}=\mathrm{T}_{\text {cell }}-2^{\circ} \mathrm{C}\right.$ ) over a long time period to ensure that the cell reached steady state. Three conditions were studied: no wetproofing, 50\% anode GDL wetproofing, and 50\% cath- (a)

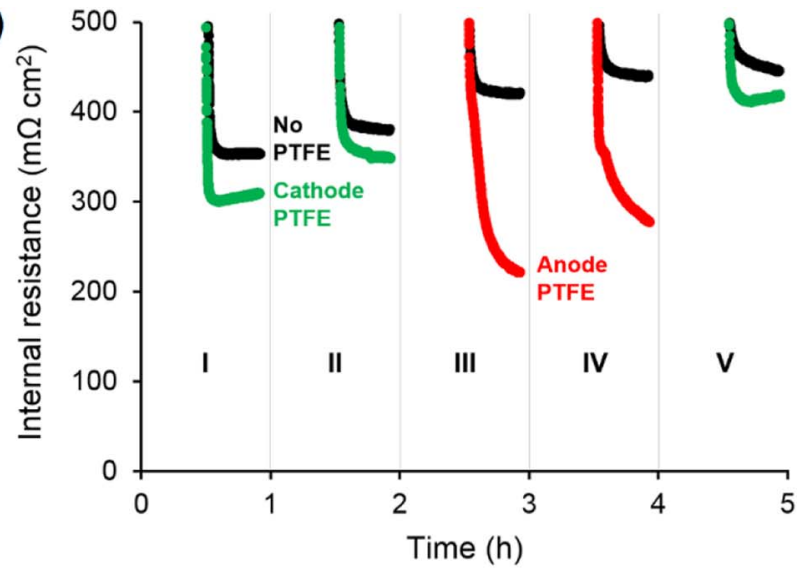

(b)

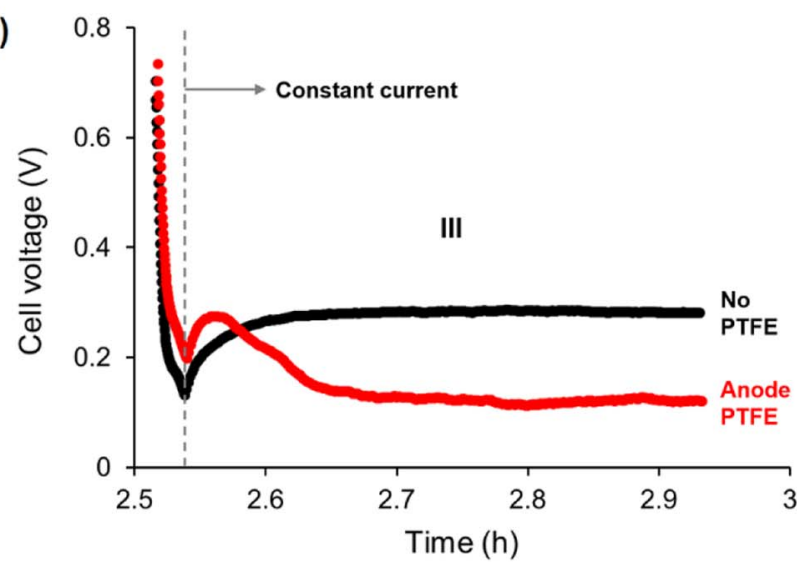

Figure 3. Impact of asymmetric wetproofing on steady-state cell water content. One MEA was assembled without wetproofing (black curves). A second MEA was assembled with one 50\% wetproofed and one unwetproofed GDL (colored curves). Each MEA was subjected to five identical one-hour tests (I, II, III, IV, and V), which consisted of a 35 min open-circuit drying period during which the feeds were replaced with dry $\mathrm{N}_{2}$, a 1 min current ramp from 0 to $170 \mathrm{~mA} \mathrm{~cm}{ }^{-2}$, and a 24 min current hold at $170 \mathrm{~mA} \mathrm{~cm}^{-2}$. (a) Internal resistance and (b) cell voltage (shown only for Test III, for clarity) were monitored continuously. At $\mathrm{t}=2 \mathrm{~h}$ and again at $\mathrm{t}=4 \mathrm{~h}$, the feeds and load cables were switched, reversing the electrode roles for Tests III and IV. Thus, the wetproofed GDL was on the cathode side for Tests I, II, and V (green), and on the anode side for Tests III and IV (red). Materials: Tokuyama A201 membrane, ionomer loading of $20 \%$ Tokuyama AS-4, catalyst loading of $0.4 \mathrm{mg}_{\mathrm{Pt}} \mathrm{cm}^{-2} \mathrm{TKK} 50 \% \mathrm{Pt} / \mathrm{C}, 0$ or $50 \%$ PTFE in Toray GDLs. Test conditions: cell at $30^{\circ} \mathrm{C}$, anode and cathode humidifiers at $28^{\circ} \mathrm{C}, \mathrm{H}_{2}$ and $\mathrm{O}_{2}$ flow rates of $0.2 \mathrm{~L} / \mathrm{min}$ at ambient pressure. Similar results were obtained at $60^{\circ} \mathrm{C}$ cell and $70^{\circ} \mathrm{C}$ humidifier temperatures (not shown). For clarity, the high IR measured at the beginning of each test (typically $2000 \mathrm{~m} \Omega \mathrm{cm}^{2}$ ) is omitted.

ode GDL wetproofing. To avoid possible differences between individually fabricated MEAs, a single MEA was used for both wetproofed conditions: by switching the feeds and load cables, the wetproofed GDL was effectively transferred from one electrode to the other with no need for cell reassembly. When no wetproofing was present the IR quickly stabilized at constant current (Fig. 3a, black curves). Similar behavior was observed with cathode wetproofing (green curves). By contrast, with anode wetproofing the IR continued to drop over time (red curves). Thus, anode wetproofing does not dry out the cell but acts as a water-retaining barrier, lowering IR and reducing ohmic losses. However, after a few minutes other losses outweighed these ohmic gains (Fig. 3b), suggesting that anode wetproofing can induce flooding even at moderate current densities $\left(170 \mathrm{~mA} \mathrm{~cm}^{-2}\right)$ under partial humidification.

While wetproofing the anode GDL dramatically lowered performance (Figs. 2-3, red coloring), wetproofing the cathode GDL had 


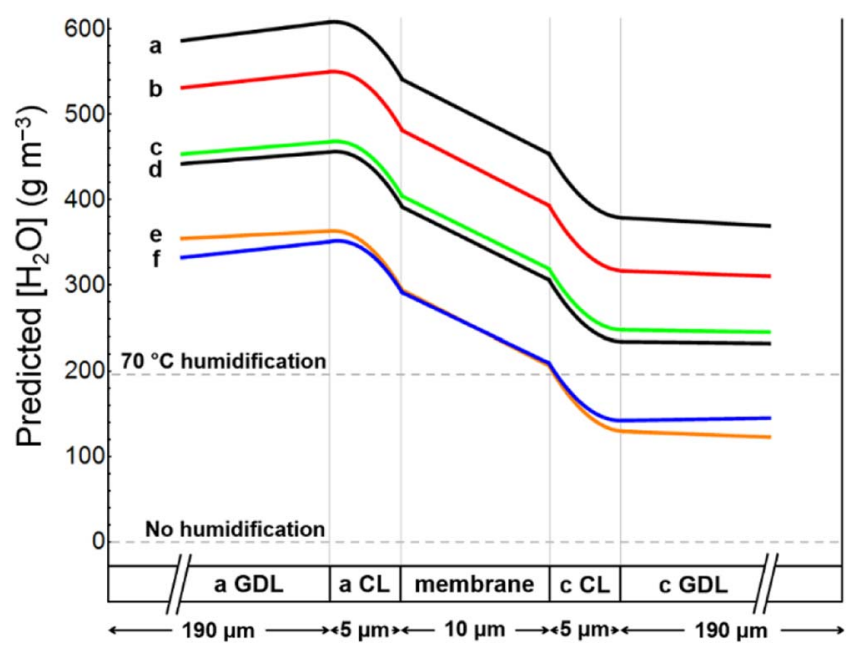

Figure 4. Cell water profiles predicted by a simplistic model. Curves a-d show the impact of GDL wetproofing, with full $70^{\circ} \mathrm{C}$ humidification in all cases: a, water diffusivity is decreased in both GDLs to simulate $50 \%$ wetproofing; $b$, only the anode GDL is wetproofed; c, only the cathode GDL is wetproofed; and d, neither GDL is wetproofed. Curves d-f show the impact of decreased humidification, with no wetproofing in all cases: $d$, both feeds are humidified at $70^{\circ} \mathrm{C}$; e, only the anode feed is humidified; and f, only the cathode feed is humidified. Unhumidified feeds are completely dry (0\% RH). The GDLs are abridged because they are over 10 times thicker than the other sandwich components. MPLs were not considered.

little impact (green coloring). Since hydrophobicity is unlikely to change after the pore walls are completely coated (approx. 10\% PTFE) ${ }^{26}$ we instead explain this discrepancy mainly through GDL pore size effects, ${ }^{27}$ in two ways. First, if flooding occurs chiefly on the anode, where water is produced, then shrinking the pores by coating the walls with PTFE should only exacerbate flooding when applied to the anode GDL.

Second, the total water content of the cell, and in turn the extent of flooding, is more sensitive to diffusivity changes in the anode GDL than in the cathode GDL. Since the anode produces more water than the cathode consumes, at steady state the net direction of water transport is out of the cell. Under equal humidification, the water concentration and diffusive potential are higher at the anode than at the cathode. ${ }^{22}$ Thus, decreasing the effective water diffusion coefficient of the GDL on the anode side, in this case by shrinking pores through wetproofing, leads to more water retention than decreasing diffusivity on the cathode.

We illustrate this water-trapping effect with a single-phase onedimensional constant-current steady-state isothermal water transport model of the HEMFC sandwich that accounts for diffusion, reaction, and electro-osmotic drag. Wetproofing was represented by a lower water diffusion coefficient in the GDL and humidification entered as the water concentration on the system boundary. Predicted cell water profiles for different combinations of wetproofed and unwetproofed GDLs are shown in Fig. 4a-4d. When both GDLs are wetproofed, water concentration is higher throughout the cell (Fig. 4a vs. Fig. 4d). However, the electrode contributions are unequal: anode wetproofing accounts for most of the profile upshift (Fig. 4b) while cathode wetproofing alone has almost no effect (Fig. 4c). This trend confirms our experimental observation that reducing anode GDL porosity via wetproofing induces catastrophic flooding. The model suggests that although cathode wetproofing is harmless on its own, the marginal impact is magnified when a large amount of water is already present at the cathode, for example due to anode wetproofing.

In PEMFCs, a common strategy to reduce cathode flooding is to add an MPL to the cathode GDL, which acts as a barrier and reroutes excess water to exit through the anode..$^{12,24,28-30}$ Surprisingly, we find that the analogous strategy in HEMFCs, namely adding an MPL to the anode to reroute water to the cathode, is ineffective. The commercial

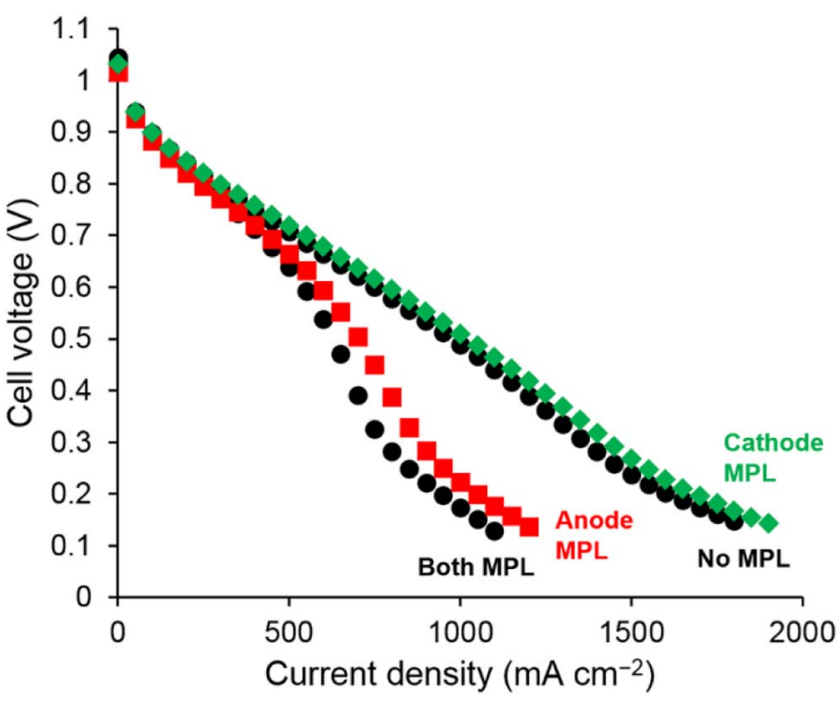

Figure 5. Impact of the MPL on cell polarization. Black circles indicate tests in which neither or both GDLs contained MPLs; green diamonds, only the cathode GDL had an MPL; and red squares, only the anode GDL had an MPL. Materials: Tokuyama A901 membrane, ionomer loading of 20\% Tokuyama AS-4, catalyst loading of $0.4 \mathrm{mg}_{\mathrm{Pt}} \mathrm{cm}^{-2} \mathrm{TKK} 50 \% \mathrm{Pt} / \mathrm{C}$. Test conditions: cell at $60^{\circ} \mathrm{C}$, anode and cathode humidifiers at $70^{\circ} \mathrm{C}, \mathrm{H}_{2}$ and $\mathrm{O}_{2}$ flow rates of $0.2 \mathrm{~L} / \mathrm{min}$ and back pressures of $250 \mathrm{kPag}$.

SGL GDLs 25 BA and 25 BC feature identical macroporous layers (190 $\mu \mathrm{m}, 5 \mathrm{wt} \%$ PTFE), but $25 \mathrm{BC}$ has an additional MPL (45 $\mu \mathrm{m}$, $10 \mathrm{wt} \%$ PTFE). We tested these GDLs with identical MEAs (Fig. 5) in the same manner as in Fig. 2. Our data corroborate the finding of Piana et al. that in the activation and ohmic regions, MPLs have little effect on polarization behavior. ${ }^{15}$ But as with the Toray paper wetproofing, an MPL on the anode GDL substantially reduces performance in the region of mass transport control. It is tempting to conclude that MPLs are inherently ineffective in HEMFCs, according to the same pore size argument presented above. There is also an alternative explanation: that since MPLs are denser than macroporous layers (here, $0.92 \mathrm{vs.}$ $0.27 \mathrm{~g} \mathrm{~cm}^{-3}$, excluding PTFE), even a low PTFE weight percentage translates to a high absolute loading. Water management in HEMFCs could require novel low-PTFE MPLs.

Still, it is unclear why PTFE seems to impact HEMFCs more strongly than PEMFCs, for which at least a small amount in the GDL and/or MPL is widely considered beneficial. ${ }^{12,24-31}$ HEMFCs operate at lower temperature due to the limited stability of currently available electrolytes, ${ }^{1}$ resulting in less evaporation and more liquid water. $^{32}$ The hydrophobic effect of wetproofing is also stronger at low temperature ${ }^{26}$ since the surface energy barrier to wetting is more significant when less thermal energy is available. Additionally, for a given current density, local water production is twice as fast on the HEMFC anode as on the PEMFC cathode, which could increase the total amount of liquid in the cell if the water consumed in ORR on the relatively dry cathode is predominantly in the vapor phase. After heavy wetproofing, the initially macroporous Toray GDLs used in this study may begin to resemble MPLs, which when free of cracks have also been found to limit liquid water transport in PEMFCs. ${ }^{26,33}$

Our results appear to conflict with strategies in which only the anode feed is humidified. Specifically, we claim that the intrinsically higher water concentration on the anode can lead to flooding (Figs. 3 and $4 \mathrm{a}-4 \mathrm{~d}$ ), while Isomura et al. obtained good performance (a peak power density, or PPD, of approx. $330 \mathrm{~mW} \mathrm{~cm}^{-2}$ ) when only the anode feed was humidified, and did not report performance under cathode-only humidification. ${ }^{16}$ We performed both experiments with our setup and observed slightly better performance with a dry anode than a dry cathode (Fig. 6). In agreement with this experimental result, our model predicts a more uniform water profile for a dry anode, with improved hydration on the cathode and alleviation of any flooding 


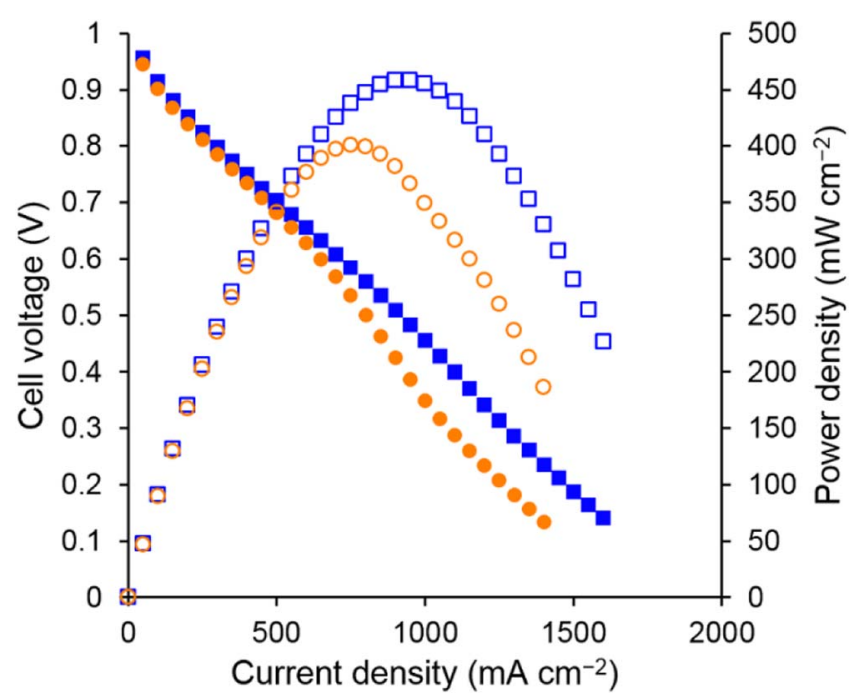

Figure 6. Performance when one feed is dry. For the orange circles, the anode was humidified (humidifier temperature: $\left.70^{\circ} \mathrm{C}\right)$ and the cathode was dry $(0 \%$ $\mathrm{RH}$ ); for the blue squares, the cathode was humidified and the anode was dry. Solid symbols indicate polarization curves and open symbols indicate power density curves. Materials: Tokuyama A901 membrane, ionomer loading of $20 \%$ Tokuyama AS-4, catalyst loading of $0.4 \mathrm{mg}_{\mathrm{Pt}} \mathrm{cm}^{-2}$ TKK $50 \% \mathrm{Pt} / \mathrm{C}$, unwetproofed Toray GDLs. Test conditions: cell at $60^{\circ} \mathrm{C}, \mathrm{H}_{2}$ and $\mathrm{O}_{2}$ flow rates of $0.2 \mathrm{~L} / \mathrm{min}$ and back pressures of $250 \mathrm{kPag}$. A test was also performed with both feeds dry, but the performance was too low to measure reliably $\left(<2 \mathrm{~mW} \mathrm{~cm}^{-2}\right.$; not shown).

on the anode, which should reduce ohmic and mass transport losses (Fig. 4e-4f). Additionally, we found previously that cathode overhumidification can improve performance. ${ }^{34}$ Overall, our findings confirm the conclusion of Isomura et al. that high performance is possible with a dry cathode feed, and additionally show that a dry anode feed is equally tenable. However, anode-only humidification may be more attractive for other practical reasons, such as improved fuel utilization via anode dead-ending. ${ }^{14}$

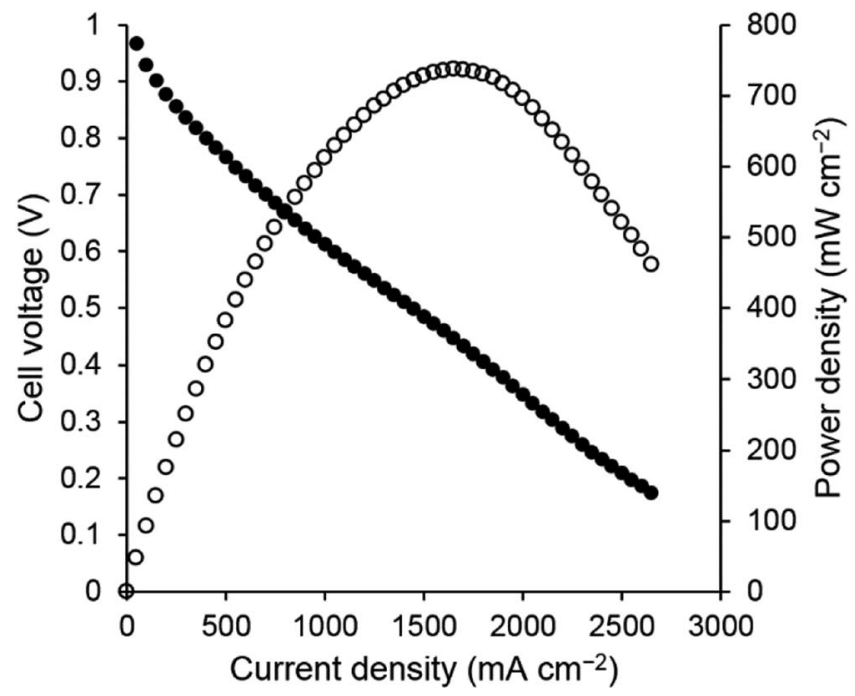

Figure 7. High-temperature performance. Solid circles indicate the polarization curve and open circles indicate the power density curve. Materials: Tokuyama A901 membrane, ionomer loading of $20 \%$ Tokuyama AS-4, catalyst loading of $0.4 \mathrm{mg}_{\mathrm{Pt}} \mathrm{cm}^{-2}$ TKK 50\% Pt/C, 5\% PTFE in Toray GDLs. Test conditions: cell at $80^{\circ} \mathrm{C}$, anode and cathode humidifiers at $85^{\circ} \mathrm{C}, \mathrm{H}_{2}$ and $\mathrm{O}_{2}$ flow rates of $0.2 \mathrm{~L} / \mathrm{min}$ and back pressures of $250 \mathrm{kPag}$.

\section{Table II. High-performance HEMFCs in the literature.}

\begin{tabular}{lccc}
\multicolumn{1}{c}{ Source } & $\begin{array}{c}\text { PPD } \\
\left(\mathrm{mW} \mathrm{cm}^{-2}\right)\end{array}$ & $\begin{array}{c}\text { Cell } \\
\text { temperature }\left({ }^{\circ} \mathrm{C}\right)\end{array}$ & $\begin{array}{c}\text { Back } \\
\text { pressure }(\mathrm{kPag})\end{array}$ \\
\hline Wang et al. $(2015)^{2}$ & 1000 & 60 & 100 \\
Mamlouk et al. $(2012)^{3}$ & 823 & 60 & 0 \\
This work & 737 & 80 & 250 \\
Isomura et al. $(2012)^{4}$ & 730 & 80 & $-^{\mathrm{a}}$ \\
Li et al. $(2013)^{5}$ & 550 & 60 & 100 \\
This work & 459 & 60 & $250^{\mathrm{c}}$ \\
Piana et al. $(2010)^{15}$ & 400 & 50 & $-{ }^{\mathrm{a}, \mathrm{b}}$ \\
Zhao et al. $(2013)^{35}$ & 338 & 60 & 50 \\
Isomura et al. $(2011)^{16}$ & $330^{\mathrm{e}}$ & 50 & $-^{\mathrm{a}, \mathrm{d}}$ \\
& & & \\
${ }^{\mathrm{a}}$ Not reported & & & \\
${ }^{\mathrm{b}} \mathrm{CO}$-free air instead of $\mathrm{O}_{2}$ as oxidant & & \\
${ }^{\mathrm{c}}$ 0\% RH in anode feed & & & \\
${ }^{\mathrm{d}}$ 0\% RH in cathode feed & &
\end{tabular}

Based on our finding that wetproofing reduces performance, we tested MEAs at high temperature with low-PTFE GDLs to mitigate flooding and maximize performance (Fig. 7). The PPD of $737 \mathrm{~mW}$ $\mathrm{cm}^{-2}$ is among the highest reported (Table II). ${ }^{2-5,15,16,35}$

\section{Conclusions}

GDL wetproofing increases HEMFC hydration. This leads to a performance tradeoff: IR is lower when the electrolyte is hydrated, but too much hydration induces mass transport losses through flooding. Under typical humidified conditions, GDLs with little or no wetproofing (0-5\% PTFE) and no MPL yield the best performance (here, a PPD of $737 \mathrm{~mW} \mathrm{~cm}^{-2}$ ). But when ohmic losses dominate, for example with a thick membrane under dry conditions, wetproofing could help to retain the water produced by HOR.

It is still possible to obtain decent performance (here, $459 \mathrm{~mW}$ $\mathrm{cm}^{-2}$ ) when only the cathode feed is humidified. Performance might be improved further by studying the contribution of ionomer loading to electrode hydrophilicity or by investigating novel MPL architectures.

\section{Acknowledgment}

This work was supported by the Advanced Research Projects Agency-Energy (ARPA-E) under award number DE-AR0000009.

\section{References}

1. J. R. Varcoe and R. C. T. Slade, Fuel Cells, 5, 187 (2005)

2. Y. Wang, G. Wang, G. Li, B. Huang, J. Pan, Q. Liu, J. Han, L. Xiao, J. Lu, and L. Zhuang, Energy Environ. Sci., 8, 177 (2015).

3. M. Mamlouk, J. A. Horsfall, C. Williams, and K. Scott, Int. J. Hydrogen Energy, 37, 11912 (2012)

4. T. Isomura, K. Fukuta, H. Yanagi, S. Ge, and C. Y. Wang, in Honolulu Pacific Rim Meeting on Electrochemical and Solid-State Science 2012, Abstract No. 1594 (2012).

5. G. Li, J. Pan, J. Han, C. Chen, J. Lu, and L. Zhuang, J. Mater. Chem. A, 1, 12497 (2013).

6. S. Lu, J. Pan, L. Zhuang, and J. Lu, Proc. Natl. Acad. Sci., 105, 20611 (2008).

7. S. Gu, W. Sheng, R. Cai, S. M. Alia, S. Song, K. O. Jensen, and Y. S. Yan, Chem. Commun., 49, 131 (2013).

8. J. H. Nam and M. Kaviany, Int. J. Heat Mass Transfer, 46, 4595 (2003).

9. A. Z. Weber and J. Newman, J. Electrochem. Soc., 152, A677 (2005).

10. T. E. Springer, T. A. Zawodzinski, and S. Gottesfeld, J. Electrochem. Soc., 138, 2334 (1991).

11. H. A. Gasteiger, S. S. Kocha, B. Sompalli, and F. T. Wagner, Appl. Catal. B, 56, 9 (2005).

12. Z. Qi and A. Kaufman, J. Power Sources, 109, 38 (2002).

13. D. Yang, H. Yu, G. Li, W. Song, Y. Liu, and Z. Shao, Chin. J. Catal., 35, 1091 (2014)

14. S. Gottesfeld, D. Dekel, Z. Gottesfeld, and D. S. Simakov, U.S. Pat. No. 8,637,196 B2 (2014).

15. M. Piana, M. Boccia, A. Filpi, E. Flammia, H. A. Miller, M. Orsini, F. Salusti, S. Santiccioli, F. Ciardelli, and A. Pucci, J. Power Sources, 195, 5875 (2010).

16. T. Isomura, K. Fukuta, H. Yanagi, S. Ge, and C. Y. Wang, in 219th The Electrochemical Society Meeting, Abstract No. 221 (2011) 
17. T. Yamanaka, T. Takeguchi, H. Takahashi, and W. Ueda, J. Electrochem. Soc., 156, B831 (2009).

18. Y. S. Li, T. S. Zhao, and W. W. Yang, Int. J. Hydrogen Energy, 35, 5656 (2010).

19. M. K. Debe and A. J. Steinbach, ECS Trans., 11, 659 (2007).

20. M. R. Hibbs, M. A. Hickner, T. M. Alam, S. K. McIntyre, C. H. Fujimoto, and C. J. Cornelius, Chem. Mater, 20, 2566 (2008).

21. M. A. Hickner, J. Polym. Sci. B: Polym. Phys., 50, 9 (2012).

22. H. Zhang, H. Ohashi, T. Tamaki, and T. Yamaguchi, J. Phys. Chem. C, 116, 7650 (2012).

23. D. Yang, H. Yu, G. Li, Y. Zhao, Y. Liu, C. Zhang, W. Song, and Z. Shao, J. Power Sources, 267, 39 (2014).

24. J. D. Fairweather, P. Cheung, and D. T. Schwarz, J. Power Sources, 195, 787 (2010).

25. L. Giorgi, E. Antolini, A. Pozio, and E. Passalacqua, Electrochim. Acta, 43, 3675 (1998).

26. C. Lim and C. Y. Wang, Electrochim. Acta, 49, 4149 (2004).
27. G. G. Park, Y. J. Sohn, T. H. Yang, Y. G. Yoon, W. Y. Lee, and C. S. Kim, J. Power Sources, 131, 182 (2004).

28. H. Li, Y. Tang, Z. Wang, Z. Shi, S. Wu, D. Song, J. Zhang, K. Fatih, J. Zhang,

H. Wang, Z. Liu, R. Abouatallah, and A. Mazza, J. Power Sources, 178, 103 (2008).

29. S. Shimpalee, U. Beuscher, and J. W. Van Zee, Electrochim. Acta, 52, 6748 (2007).

30. G. Velayutham, J. Kaushik, N. Rajalakshmi, and K. S. Dhathathreyan, Fuel Cells, 7, 314 (2007).

31. M. Prasanna, H. Y. Ha, E. A. Cho, S. A. Hong, and I. H. Oh, J. Power Sources, 131, 147 (2004).

32. K. Tüber, D. Pócza, and C. Hebling, J. Power Sources, 124, 403 (2003)

33. M. P. Manahan, S. Kim, E. C. Kumbur, and M. M. Mench, ECS Trans., 25, 1745 (2009).

34. S. Gu, R. Cai, T. Luo, Z. Chen, M. Sun, Y. Liu, G. He, and Y. S. Yan, Angew. Chem. Int. Ed., 48, 6499 (2009).

35. Y. Zhao, H. Yu, D. Yang, J. Li, Z. Shao, and B. Yi, J. Power Sources, 221, 247 (2013). 